\section{Self-incompatibility alleles in important genotypes for apple breeding in Brazil}

\section{Thyana Lays Brancher ${ }^{1^{*}}$, Maraisa Crestani Hawerroth ${ }^{2}$, Marcus Vinícius Kvitschal ${ }^{2}$, Danielle Caroline Manenti ${ }^{3}$ and Altamir Frederico Guidolin ${ }^{4}$}

\begin{abstract}
The objective of this study was to identify self-incompatibility (S) alleles of advanced breeding selections of apple (Malus $\times$ domestica Borkh.). The Salleles of 42 apple genotypes were analyzed by markers using allele-specific PCR amplification and amplicons digested with restriction endonucleases. Among the screened genotypes were cultivars, advanced selections, and accessions of the Apple Germplasm Bank of Epagri (Caçador, Santa Catarina, Brazil). Two $S$-alleles were identified in 36 genotypes, and only one S-allele was determined in the other six genotypes. In all, eleven S-alleles were identified among all the genotypes evaluated. The $S_{3}$ and $S_{5}$ alleles were most frequent $(30.2 \%$ and $18.6 \%$, respectively). The identification of S-alleles using molecular markers in important apple tree genotypes is useful for determination of compatible parents for breeding programs.
\end{abstract}

Keywords: Malus $\times$ domestica Borkh., artificial hybridization, S-RNases, S-alleles.

\section{INTRODUCTION}

The development of new apple cultivars (Malus $\times$ domestica Borkh.) by classical breeding methods requires from 13 to 17 years of research (Sedov 2014). The process begins with the choice of parents that have traits of interest, which are then crossed to select new cultivars and their pollinizers (Denardi et al. 2019a). The possible parental combinations are restricted by the gametophytic self-incompatibility (GSI) system present in Malus (Pereira-Lorenzo et al. 2018). The GSI of a fertile plant is its inability to produce zygotes after self-pollination or pollination among individuals that have $S$-alleles in common (Muñoz-Sanz et al. 2020). The $S$-locus is responsible for determining self-incompatibility and is positioned on chromosome 17 of the apple genome (Maliepaard et al. 1998). Crosses between genetically compatible plants (even between species) are required to generate as many plants as possible with the greatest genetic variability (De Franceschi et al. 2016). The S-alleles of several apple cultivars and genotypes have not been genotyped, making it difficult to choose compatible parents for planned crosses.

Traditionally, the presence of S-alleles was determined indirectly by pollination and pollen tube growth tests (Bošković and Tobutt 1999), but this methodology is strongly influenced by the environment and requires replications in different growing seasons to ensure the reliability of this identification (Breen et al. 2016). The use of genetic markers to identify $S$-alleles, such as allele-specific
Crop Breeding and Applied Biotechnology 20(4): e28652041, 2020 Brazilian Society of Plant Breeding. Printed in Brazil http://dx.doi.org/10.1590/198470332020v20n4a54

\author{
*Corresponding author: \\ E-mail: thyanabrancher@gmail.com \\ (D) ORCID: 0000-0003-3337-6314 \\ Received: 01 August 2019 \\ Accepted: 15 April 2020 \\ Published: 15 October 2020
}

\footnotetext{
${ }^{1}$ Universidade Federal de Lavras, Campus Universitário, 37.200-000, Lavras, MG, Brazil ${ }^{2}$ Empresa de Pesquisa Agropecuária e Extensão Rural de Santa Catarina, Estação Experimental de Caçador, Abílio Franco, 89.501-032, Caçador, SC, Brazil

${ }^{3}$ Universidade Estadual de Maringá, Colombo, 5790, 87.020-900, Maringá, PR, Brazil ${ }^{4}$ Universidade do Estado de Santa Catarina, Centro de Ciências Agroveterinárias, Luiz de Camões, 2090, 88.520-000, Lages, SC, Brazil
} 


\section{TL Brancher et al.}

primers, provides information on their distribution among apple genotypes (Long et al. 2010, Akbari et al. 2016, Larsen et al. 2016, Kasajima et al. 2017) and allows breeders to plan crosses between compatible genotypes (Morita et al. 2009, Breen et al. 2016).

In the GSI mechanism, if the pollen has the same $S$-allele as the pistil, the developed pollen-tubes are recognized and rejected by a pistil-specific ribonuclease (S-RNase) encoded by the $S$-locus. The $S$-RNase is always expressed in the pistil, but when the $S$-allele of the pollen is not the same as either of the two $S$-alleles expressed in the pistil, the $S$-RNases are inactivated by at least two genes specifically expressed in pollen - S-locus F-box Brother genes (Sassa et al. 2007). To date, 57 S-alleles of the Malus S-locus encoding a different S-RNase have been identified (Kim et al. 2016).

The only active public apple breeding program in Brazil is at the Agricultural Research and Rural Extension Company of Santa Catarina (Epagri), located at the Experimental Stations of Caçador and São Joaquim, SC. For breeding crosses, the Epagri Apple Breeding Program uses selections and cultivars resulting from their own crosses and/or those developed in other countries as parents. It is crucial for this breeding program to choose fully compatible parents for the planned crosses. The objective of the study was to use genetic markers to identify the $S$-alleles of 42 apple genotypes/cultivars used as parents in the Epagri Apple Breeding Program.

\section{MATERIAL AND METHODS}

Among the apple genotypes used in the Epagri Apple Breeding Program, a total of 42 were tested (Table 1). Of these, six are cultivars developed by Epagri, 20 are advanced selections developed by the Epagri Apple Breeding Program, and 16 are accessions from the Epagri Apple Germplasm Bank. These genotypes were grown in experimental orchards and on the premises of the Apple Germplasm Bank at the Epagri Experimental Station in the municipality of Caçador in the Midwestern region of the state of Santa Catarina (lat 26 49' 5" S, long $50^{\circ} 59^{\prime} 12^{\prime \prime}$ W, alt $940 \mathrm{~m}$ asl).

Young and healthy leaves were collected from the 42 apple genotypes and deep frozen at -20 ㅇ $\mathrm{C}$ in plastic bags until DNA extraction, which was performed according to the protocol proposed by Lefort and Douglas (1999) with modifications (Revers et al. 2005), using $0.1 \mathrm{~g}$ of ground plant tissue.

Table 1. The apple cultivars and the apple selections analyzed in this study and their parents

\begin{tabular}{|c|c|c|c|c|c|}
\hline $\begin{array}{l}\text { Cultivar/ } \\
\text { selection }\end{array}$ & Parent $1(\uparrow)$ & Parent $2\left({ }^{\lambda}\right)$ & $\begin{array}{l}\text { Cultivar/ } \\
\text { Selection }\end{array}$ & Parent $1(+)$ & Parent $2\left({ }^{\lambda}\right)$ \\
\hline $21-300-21^{1}$ & Unknown & Unknown & $M-11 / 00^{2}$ & Fred Hough [S5S19] & Imperatriz [S3S5] \\
\hline $21-373-58^{1}$ & Unknown & Unknown & $M-11 / 92^{2}$ & $M-41$ & Gala [S2S5] \\
\hline $21-379-64^{1}$ & Unknown & Unknown & $\mathrm{M}-12 / 00^{2}$ & Fred Hough [S5S19] & Imperatriz [S3S5] \\
\hline $141 / 38^{2}$ & Baronesa [S3S9] & O.p. & $M-15 / 01^{2}$ & Fred Hough [S5S19] & Imperatriz [S3S5] \\
\hline Co-op $8^{3}$ & PRI 558-1 & Mollie's Delicious [S3S7] & $M-21 / 08^{2}$ & $M-47 / 94$ & Princesa [S3S5] \\
\hline Co-op $14^{3}$ & PRI 10-147 & Mollie's Delicious [S3S7] & $M-23 / 07^{2}$ & $M-46 / 94$ & $M-13 / 91$ \\
\hline Co-op $16^{3}$ & PRI 764 & PRI 672 & $M-3 / 02^{2}$ & Fred Hough [S5S19] & Imperatriz [S3S5] \\
\hline Co-op $24^{3}$ & NJ. 125355 & Prima [S2S10] & $M-4 / 09^{2}$ & Imperatriz [S3S5] & Catarina [S1S19] \\
\hline Galaxy $^{6}$ & \multicolumn{2}{|c|}{ Sport mutation of Gala } & $\mathrm{M}-8 / 01^{2}$ & Fred Hough [S5S19] & Imperatriz [S3S5] \\
\hline Macfree $^{7}$ & McIntosh [S10S25] & $48-177$ & $M-9 / 07^{2}$ & $M-46 / 94$ & Imperatriz [S3S5] \\
\hline SCS417 Monalisa ${ }^{4}$ & Gala [S2S5] & Malus 4 & Scifresh ${ }^{6}$ & Braeburn [S9S24] & Gala [S2S5] \\
\hline SCS426 Venice $^{4}$ & Imperatriz [S3S5] & Baronesa [S3S9] & SCS427 Elenise ${ }^{4}$ & Imperatriz [S3S5] & Cripps Pink [S2S23] \\
\hline$M-1 / 02^{2}$ & Fred Hough [S5S19] & Imperatriz [S3S5] & SCS416 Kinkas ${ }^{4}$ & Fuji [S1S9] & PWR37T133 \\
\hline$M-1 / 07^{2}$ & $M-47 / 94$ & Princesa [S3S5] & SCS425 Luiza ${ }^{4}$ & Imperatriz [S3S5] & Cripps Pink [S2S23] \\
\hline
\end{tabular}

O.p: open pollinated. ${ }^{1}$ Selections from Argentina. ${ }^{2}$ Selections from the Epagri Apple Breeding Program. ${ }^{3}$ Selections from the PRI disease-resistant apple breeding program. ${ }^{4}$ Cultivar developed by Epagri. ${ }^{5}$ Selections from USA. ${ }^{6}$ Cultivar from New Zealand. ${ }^{7}$ Cultivar from Ottawa Research Station breeding program. 
Each polymerase chain reaction (PCR) contained $1 \mathrm{U}$ of Taq DNA polymerase, $1 x$ enzyme buffer, $2.00 \mathrm{mM} \mathrm{MgCl}{ }_{2}$, $0.2 \mathrm{mM}$ dNTPs, $1 \mu \mathrm{M}$ of each primer (forward and reverse), and $50 \mathrm{ng}$ of genomic DNA, with a final volume of $15 \mu \mathrm{L}$. Primers for the identification of $16 S$-alleles of apple trees were used: $S_{1^{\prime}}, S_{2^{\prime}} S_{3^{\prime}} S_{4^{\prime}}, S_{5^{\prime}}, S_{6^{\prime}} S_{7^{\prime}}, S_{9}, S_{10^{\prime}} S_{16^{\prime}} S_{19^{\prime}} S_{20^{\prime}} S_{22^{\prime}} S_{23^{\prime}}$ $S_{24}$, and $S_{26}$ (Table 2).

The PCRs were performed in a $1100^{\mathrm{TM}}$ thermocycler (BioRad ${ }^{\circ}$, California, USA) programmed for 3 min at $94^{\circ} \mathrm{C}$, followed by 30 cycles of $94^{\circ} \mathrm{C}$ for $1 \mathrm{~min}$, annealing at $54-62^{\circ} \mathrm{C}$ (depending on the primer characteristics; see Table 2) for $1 \mathrm{~min}$, and $72{ }^{\circ} \mathrm{C}$ for $1 \mathrm{~min}$, followed by a final extension step $\left(72^{\circ} \mathrm{C}\right.$ for $\left.7 \mathrm{~min}\right)$.

Table 2. S-alleles tested for apple, respective sequences of each primer, and specific PCR conditions. Values in parentheses indicate the fragment size generated by digestion with the respective restriction enzymes

\begin{tabular}{|c|c|c|c|c|}
\hline$S$-allele & Primers & Sequences $\left(5^{\prime}->3^{\prime}\right)$ & $\begin{array}{l}\text { Annealing temperature } \\
\text { oC, enzyme }\end{array}$ & $\begin{array}{l}\text { Amplified fragment } \\
\text { (bp) }\end{array}$ \\
\hline $\mathrm{S}_{1}$ & FTC169 & GGTTCTGTATTGGGGAAGACGCACAA & 60 & 530 \\
\hline $\mathrm{S}_{2}$ & OWB123 & GGTTTGGTTCCTTACCATGG & 60 & 449 \\
\hline $\mathrm{S}_{3}$ & FTC177 & CAAACGATAACAAATCTTAC & 55 & 500 \\
\hline $\mathrm{S}_{4}$ & OWB249 & CAATCTATGAAATGTGCTCTG & 60, Taql & $274(194+77)$ \\
\hline \multirow[b]{2}{*}{$\mathrm{S}_{5}$} & FTC10 & CAAACATGGCACCTGTGGGTCTCC & \multirow{2}{*}{59} & \multirow{2}{*}{346} \\
\hline & FTC11 & TAATAATGGATATCATTGGTAGG & & \\
\hline \multirow[b]{2}{*}{$\mathrm{S}_{6}$} & FTC141 & ATCAGCCGGCTGTCTGCCACTC & \multirow{2}{*}{$58^{\mathrm{E} 45}$} & \multirow{2}{*}{850} \\
\hline & FTC142 & AGCCGTGCTCTTAATACTGAATAC & & \\
\hline $\mathrm{S}_{9}$ & OWB155 & CGGTTCGATCGAGTACGTTG & 62 & 343 \\
\hline \multirow{2}{*}{$\mathrm{S}_{10}$} & FTC12 & CCAAACGTACTCAATCGAAG & \multirow{2}{*}{60} & \multirow{2}{*}{209} \\
\hline & FTC228 & ATGTCGTCCCGTGTCCTGAATC & & \\
\hline \multirow{2}{*}{$S_{10}$ modified' } & & AACAAATCTTAAAGCCCAGC & & \\
\hline & & GGTTTCTTATAGTCGATACTTTG & 60, Narl & - \\
\hline & & CAATTTACGCAGCARTATCAG & & \\
\hline$S_{3} / S_{5} / S_{10}$ & & TGTTTTGAATYGAAAATTARTTAGGAGT & 58 & - \\
\hline & FTC5 & TCCCACAATACAGAACGAGA & 60 Tagl & $274(243+41)$ \\
\hline $\mathrm{S}_{16}$ & OWB249 & CAATCTATGAAATGTGCTCTG & $60, \mid a q 1$ & $2 / 4(243+41)$ \\
\hline$c$ & FTC229 & TCTGGGAAAGAGAGTGGCTC & 00 & 304 \\
\hline & FTC231 & AAATATTGCAACGCACAGCA & & \\
\hline $\mathrm{S}_{24}$ & FTC232 & TTGAGAGGATTTCAGAGATG & 60 & 580 \\
\hline & FCT14 & GAAGATGCCATACGCAATGG & & \\
\hline$S_{26}$ & FTC9 & TTTAATACCGAATATTGGCG & 54 & 194 \\
\hline
\end{tabular}

$\mathrm{E} 45$ = Extension of $45 \mathrm{sec}$. 'Primer proposed by Kitahara \& Matsumoto (2002). Reaction conditions: 3 min at $94{ }^{\circ} \mathrm{C}$, followed by 30 cycles at $94{ }^{\circ} \mathrm{C}$ for 1 min, $60{ }^{\circ} \mathrm{C}$ for 1 min, and $72^{\circ} \mathrm{C}$ for $1 \mathrm{~min}$, with a final extension step at $72{ }^{\circ} \mathrm{C}$ for $10 \mathrm{~min}$, set at $4{ }^{\circ} \mathrm{C}$ after concluding amplification. Amplified fragment of $282 \mathrm{bp}$ for the $\mathrm{S}$-alleles and after treatment with enzyme Narl generates two fragments: 185 and $97 \mathrm{bp}$. "Primer proposed by Larsen et al. (2016) for the identification of alleles $S$ S and $S$. Reaction conditions: 2 min at $94{ }^{\circ} \mathrm{C}$, followed by 33 cycles at $94^{\circ} \mathrm{C}$ for $20 \mathrm{sec}, 58^{\circ} \mathrm{C}$ for $20 \mathrm{sec}$, and $72{ }^{\circ} \mathrm{C}$ for 2 min, with a final step of $72{ }^{\circ} \mathrm{C}$ for 5 min, maintaining a fixed temperature of $4{ }^{\circ} \mathrm{C}$ after concluding amplification. Alleles with respective amplified fragment size before and after the treatment with enzyme Taql: $S_{3}=423 \mathrm{bp}, 264 \mathrm{bp} ; S_{5}=399 \mathrm{bp}, 273 \mathrm{bp}$; $S_{10}=382 \mathrm{bp}$, not fragmented by the restriction enzyme. FTC and OWB primers were developed by Broothaerts (2003). 


\section{TL Brancher et al.}

For discrimination of the $S_{4}, S_{16}$, and $S_{22}$ alleles, part of the PCR product $(10 \mu \mathrm{L})$ was digested by the restriction enzyme Taql (for $1 \mathrm{~h}$ in a $65^{\circ} \mathrm{C}$ water bath). Likewise, for identification of the $S_{20}$ allele, $10 \mu \mathrm{L}$ of the PCR product was digested by the restriction enzyme $\mathrm{Narl}$ (for $4 \mathrm{~h}$ in a $37^{\circ} \mathrm{C}$ water bath). For the $S_{10}$ modified and $S_{3} / S_{5} / S_{10}$ primers, PCR programming and restriction enzyme digestion are described in Table 2.

As a positive control for the presence of each $S$-allele, cultivars previously characterized for the respective $S$-allele were used (Table 3). The only exception was the $S_{16}$ allele since no genotype is maintained by Epagri with this pre-identified allele. In addition, the same cultivars were used for primer optimization.

After PCR and respective digestions with restriction enzymes, if necessary, the amplification products were analyzed by $3 \%$ agarose gel electrophoresis using the $50 \mathrm{bp}$ DNA marker to help identify the size of the PCR product. The gels were stained with GelRed (Biotium, California, USA) and then observed and photographed with Kodak Gel Logic 212 Pro (Carestream, New York, USA), for registration and interpretation. The samples with bands that coincided with the size of the respective $S$-allele amplifications (Table 2) were considered to be present.

\section{RESULTS AND DISCUSSION}

At least one $S$-allele was identified in each genotype characterized (Table 4). The genotypes 'Castel Gala' (Epagri Apple Breeding cultivar) and 'Galaxy' were identified as $S_{2} S_{5}$. They are sport mutations of 'Gala' for early budding and skin color, respectively (Hawerroth et al. 2018, Denardi et al. 2019a), and as originally expected, had the same genotype as the original cultivar (Matsumoto et al. 1999).

Among the genotypes tested, the genotypes 21-300-21, 21-361-75, Co-op 24, M-11/92, 'MacFree', and 'SCS416 Kinkas' manifested only one of the $S$-alleles identified with the primer set used in this study: $S_{9} S_{?}, S_{9} S_{?}, S_{2} S_{?}, S_{2} S_{?}, S_{20} S_{?}$,

Table 3. Apple cultivars used as positive controls for the presence of each S-allele, their S-alleles reported in the literature, and respective references

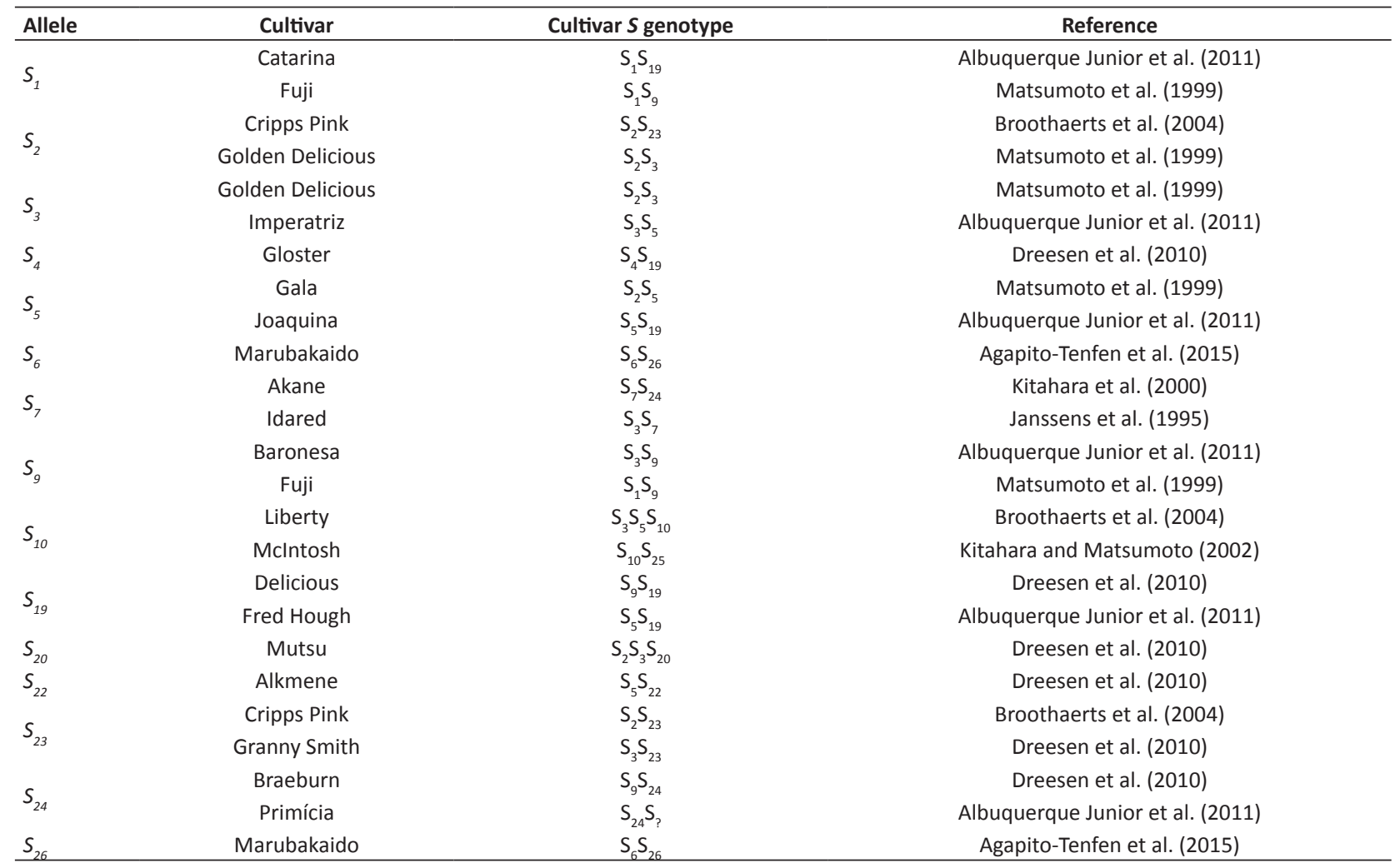

$S$ : another unidentified $S$-allele. 
Table 4. S-alleles identified in relevant apple genotypes for the Epagri Apple Breeding Program

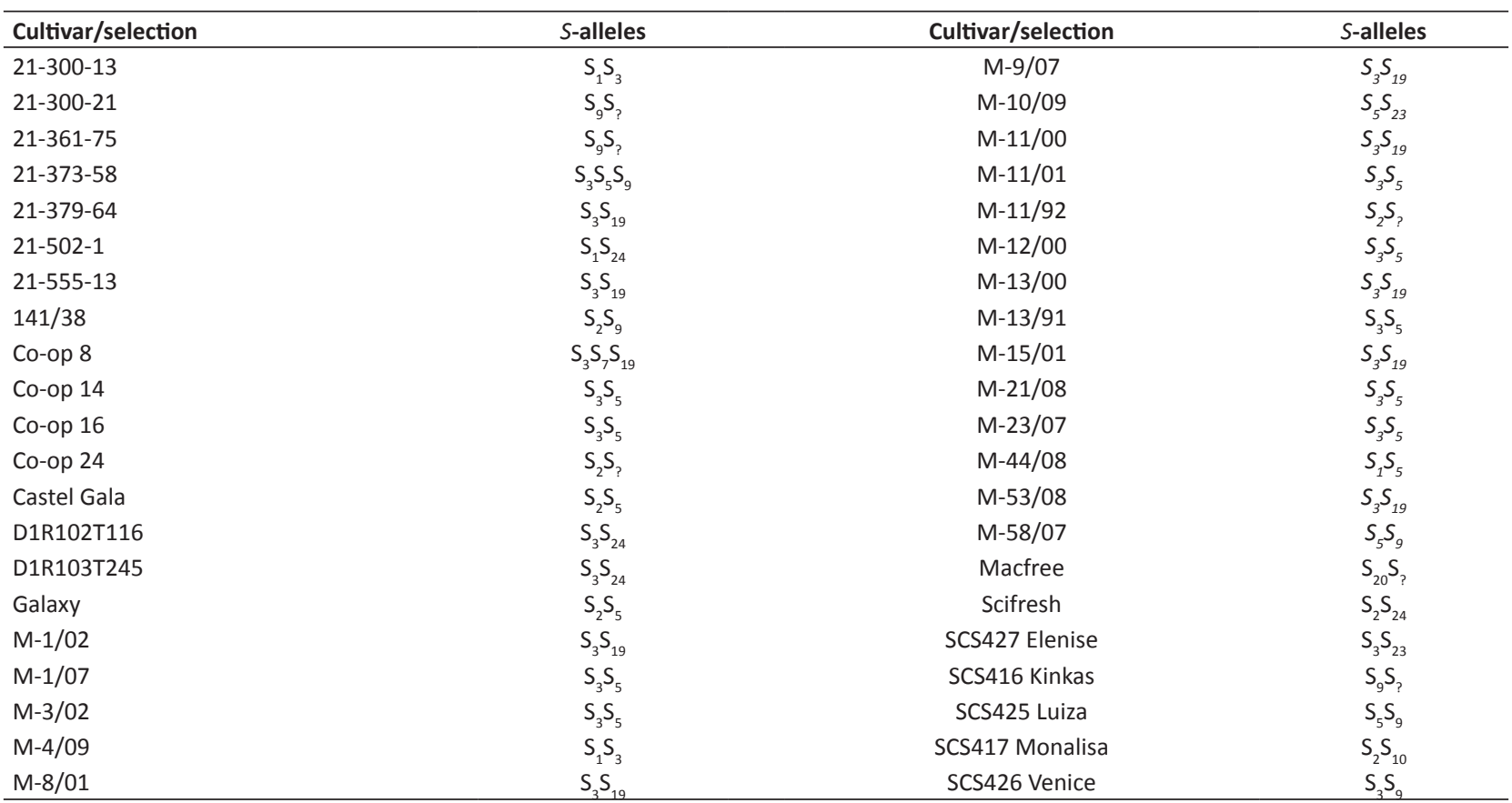

$S_{\text {: }}$ another unidentified $S$-allele.

and $S_{9} S_{2}$, respectively. New markers are required for identification of the second $S$-allele of these genotypes, for example, through use of the markers developed by Larsen et al. (2016), which identify S-alleles found at a lower frequency among apple cultivars. It is noteworthy that these low-frequency $S$-alleles were not evaluated initially in the present study because they are not commonly found in genotypes developed in Brazil (Albuquerque Junior et al. 2011). The cultivar 'SCS416 Kinkas' $\left(S_{9} S_{2}\right)$ is the result of the cross between 'Fuji' $\left(S_{1} S_{9}\right)$ and PWR37T133 (S-alleles unknown), while M-11/92 $\left(S_{2} S_{?}\right)$ is a descendant of the cross between M-41 [Anna ${ }_{1}\left(S_{3} S_{29}\right) \times$ NJ-56 $\widehat{\jmath}$ (S-alleles unknown)] and Gala $\left(S_{2} S_{5}\right)$. Both genotypes have unknown $S$-alleles in their genealogy and were able to exhibit $S$-alleles other than those we attempted to genotype in this study.

The genotype $S_{3} S_{5}$ was determined for the selections $M-3 / 02, M-11 / 01$, and $M-12 / 00$, while $S_{3} S_{19}$ was identified for 'M-1/02', 'M-8/01', 'M-11/00', 'M-13/00', and 'M-15/01'. These selections have the same semi-compatible parents, 'Fred Hough' $\left(S_{5} S_{19}-9\right)$ and 'Imperatriz' $\left(S_{3} S_{5}-\lambda\right)$. All the genotypes had the expected segregation of this cross. As reported by De Franceschi et al. (2016), the semi-compatibility between parents causes the abortion of pollen carrying the common $S$-allele when coming in contact with the pistil of a semi-compatible plant.

For the selection $M-13 / 91$, a $S_{3} S_{5}$ genotype was detected, which is different from the $S_{5} S_{10}$ previously reported by Albuquerque Junior et al. (2011). This confirms the pedigree of 'M-13/91' ['Mollie's Delicious' $\left(S_{3} S_{7}-P_{1}\right) \times$ 'Princesa' $\left(S_{3} S_{5}\right.$ - $\left.\hat{O}^{\top}\right)$ ], whose parents do not carry the $S_{10}$ allele. Using the FTC12 and FTC228 primers, an allele size corresponding to the $S_{10}$ allele (209 bp) occurred in the selection M-13/91. However, when using the ' $S_{10}$ modified' marker recommended by Kitahara and Matsumoto (2002), the amplification of the expected region in 'M-13/91' was not confirmed. In contrast, for 'SCS417 Monalisa' $\left(S_{2} S_{10}\right)$, the amplification product generated by the ' $S_{10}$ modified' marker treated with restriction enzyme Narl generated specific fragments (185 and $97 \mathrm{bp}$ ), indicating the presence of the $S_{10}$ allele. Likewise, when using the ' $S_{3} / S_{5} / S_{10}$ ' marker for genotyping of the selection M-13/91, fragments characteristic of $S_{3}$ (423 bp and 264 bp) and $S_{5}\left(399 \mathrm{bp}\right.$ and $273 \mathrm{bp}$ ) alleles were amplified, but not of $S_{10}(382 \mathrm{bp})$. In addition, the final amplified product was $382 \mathrm{bp}$ for the cultivar 'SCS417 Monalisa' when using the ' $S_{3} / S_{5} / S_{10}$ ' marker, a size characteristic of the $S_{10}$ allele (Larsen et al. 2016). Based on the sequences of the available $S$-alleles (Benson et al. 2013), alleles $S_{3}$ (GenBank code: U12200.1) and $S_{10}$ (GenBank code: AB052683.1) have a percentage of identity of $96 \%$. The $S_{3}$ and $S_{5}$ alleles (GenBank 


\section{TL Brancher et al.}

code: U19791.1) have a sequence identity of 77\%, and the $S_{5}$ and $S_{10}$ alleles, 90\%. Therefore, the data suggest that the primers FTC12 and FTC228 match homologous sequences at the three alleles $\left(S_{3}, S_{5}\right.$, and $\left.S_{10}\right)$, impairing the use of these primers for identification of the $S_{10}$ allele, thus explaining the discrepancy in genotyping compared to results of Albuquerque Junior et al. (2011).

According to the official pedigree, the cultivar 'SCS425 Luiza' is a descendant of 'Imperatriz' $\left(S_{3} S_{5}\right.$ - + ) and 'Cripps Pink' $\left(S_{2} S_{23}-{ }^{\top}\right)$ (Denardi et al. 2019b), and is a sibling of 'SCS427 Elenise' and 'M-10/09' (Table 1). The S-allele genotypes were $S_{3} S_{23}$ and $S_{5} S_{23}$ for the cultivar 'SCS427 Elenise' and selection M-10/09, respectively. However, 'SCS425 Luiza' exhibited the genotype $S_{5} S_{9}$, which was not expected, based on its genealogy. So, the presence of the $S_{9}$ allele in 'SCS425 Luiza' indicates that there may have been cross contamination during the development of the cultivar (pollen contamination, seed exchange between crosses at sowing, or hybrid exchange at planting) or that this cultivar is not the result of the cross 'Imperatriz' x 'Cripps Pink'. Consequently, the true pedigree of 'SCS425 Luiza' must be determined. Similar results have been reported in the literature. Sakurai et al. (2000) admitted the possibility of cross contamination during the development of the cultivar 'Kent' $\left(S_{3} S_{9}\right)$. In this case, this cultivar was theoretically a descendant from 'Cox's Orange Pippin' $\left(S_{5} S_{9}-+\right) \times$ 'Jonathan' $\left(S_{7} S_{9}-J^{J}\right)$. For that reason, these authors suggested that 'Jonathan' is not the true pollen donor of the cultivar 'Kent'. In this sense, the genotyping of the $S$-alleles in the present study generated information that show possible errors in the genealogy previously registered by the Epagri Apple Breeding Program. Thus, $S$-allele

Table 5. Level of compatibility among the genotypes evaluated in this study based on their S-alleles

\begin{tabular}{|c|c|c|c|c|c|c|c|c|c|c|c|c|c|c|c|c|c|c|c|}
\hline Genotype & $\begin{array}{l}\text { ㄱ. } \\
\stackrel{0}{0} \\
\text { o } \\
\text { o }\end{array}$ & $\begin{array}{l}\text { N } \\
\text { oñ } \\
\text { o }\end{array}$ & $\begin{array}{l}m \\
\text { no } \\
\text { 인 }\end{array}$ & $\begin{array}{l}\text { ナ } \\
\circ \\
\stackrel{0}{3} \\
\text { o }\end{array}$ & $\begin{array}{l}\text { n } \\
\text { 음 } \\
\text { ơ }\end{array}$ & $\begin{array}{l}0 \\
\circ \\
0 \\
0\end{array}$ & $\begin{array}{l}\hat{0} \\
\text { 음 } \\
\text { ơ }\end{array}$ & $\begin{array}{l}\infty \\
\circ \\
0 \\
0 \\
0\end{array}$ & $\begin{array}{l}{ }_{0}^{*} \\
\stackrel{n}{*} \\
\stackrel{n}{n} \\
\stackrel{n}{n} \\
\stackrel{n}{N}\end{array}$ & 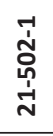 & 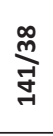 & $\begin{array}{l}\text { * } \\
\text { o } \\
0 \\
0 \\
\dot{0} \\
\dot{3}\end{array}$ & 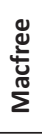 & 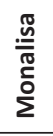 & 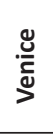 & $\frac{9}{\stackrel{2}{0}}$ & 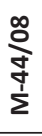 & 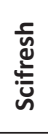 & 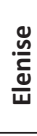 \\
\hline $\begin{array}{l}\text { Group } 3\left(S_{g} S_{?}\right) \\
21-300-21,21-361-75, \text { SCS416 } \\
\text { Kinkas }\end{array}$ & C & C & - & & & & & & & & & & & & & & & & \\
\hline $\begin{array}{l}\text { Group } 4\left(S_{2} S_{?}\right) \\
\text { Co-op 24, M-11/92 }\end{array}$ & C & $\mathrm{C}$ & $\mathrm{SC}^{*}$ & - & & & & & & & & & & & & & & & \\
\hline $\begin{array}{l}\text { Group } 7\left(S_{5} S_{9}\right) \\
\text { M-58/07, SCS425 Luiza }\end{array}$ & SC & C & SC & C & C & C & - & & & & & & & & & & & & \\
\hline $\begin{array}{l}\text { Group } 8\left(S_{2} S_{5}\right) \\
\text { Castel Gala, Galaxy }\end{array}$ & SC & C & $C$ & SC & C & $C$ & SC & - & & & & & & & & & & & \\
\hline $21-373-58 * *$ & I & SC & SC & $\mathrm{C}$ & SC & SC & SC & SC & - & & & & & & & & & & \\
\hline $21-502-1$ & $\mathrm{C}$ & $\mathrm{C}$ & $\mathrm{C}$ & $\mathrm{C}$ & SC & SC & $\mathrm{C}$ & C & $\mathrm{C}$ & - & & & & & & & & & \\
\hline $141 / 38$ & $C$ & $\mathrm{C}$ & SC & SC & C & $C$ & SC & SC & SC & C & - & & & & & & & & \\
\hline Co-op 8 & $\mathrm{SC}$ & SC & $\mathrm{C}$ & $\mathrm{C}$ & SC & SC & $\mathrm{C}$ & $\mathrm{C}$ & - & $\mathrm{C}$ & $\mathrm{C}$ & - & & & & & & & \\
\hline Macfree & $\mathrm{C}$ & $\mathrm{C}$ & $\mathrm{SC}^{*}$ & $\mathrm{SC}^{*}$ & $\mathrm{C}$ & $\mathrm{C}$ & $\mathrm{C}$ & $C$ & C & $\mathrm{C}$ & C & $C$ & - & & & & & & \\
\hline SCS417 Monalisa & $\mathrm{C}$ & $\mathrm{C}$ & $\mathrm{C}$ & SC & $\mathrm{C}$ & $C$ & $\mathrm{C}$ & SC & C & $\mathrm{C}$ & SC & $\mathrm{C}$ & $\mathrm{C}$ & - & & & & & \\
\hline
\end{tabular}

Genotypes in the groups are incompatible - they have the same $S$-alleles. "At least semi-compatible genotypes. ${ }^{* *} U$ sing triploid genotypes as female parent. 
genotyping by markers can be used as an auxiliary tool in the characterization of the descendants of apple crosses, taking the expected segregation of S-alleles into account.

The Epagri apple selections and the apple cultivar 'SCS426 Venice' were characterized by the presence of two $S$-alleles (Table 4), and this presence is consistent with the possibility of those $S$-alleles having been inherited from their parents, Imperatriz ( $(+)$ and Baronesa ( $\left.{ }^{\lambda}\right)$ (Denardi et al. 2019c). Two $S$-alleles were also found for the selections $141 / 38\left(S_{2} S_{9}\right.$ - the $S_{9}$ is from the parental 'Baronesa' and the other $S$-allele is from open pollination), M-1/07 $\left(S_{3} S_{5}\right), M-21 / 08\left(S_{3} S_{5}\right)$, $\mathrm{M}-23 / 07\left(S_{3} S_{5}\right), \mathrm{M}-4 / 09\left(S_{1} S_{3}\right), \mathrm{M}-44 / 08\left(S_{1} S_{5}\right), \mathrm{M}-53 / 08\left(S_{3} S_{19}\right), \mathrm{M}-58 / 07\left(S_{5} S_{9}\right), \mathrm{M}-9 / 07\left(S_{3} S_{19}\right)$, and the cultivar SCS426 Venice $\left(S_{3} S_{9}\right)$. Three $S$-alleles were identified for the cultivars 21-373-58 $\left(S_{3} S_{5} S_{9}\right)$ and Co-op $8\left(S_{3} S_{7} S_{19}\right)$. Three $S$-alleles were also identified in other genotypes previously known as triploid (Broothaerts et al. 2004, Dreesen et al. 2010, AgapitoTenfen et al. 2015), and there is no more molecular information in the literature about these two cultivars that could confirm triploidy. The others were identified as diploid genotypes: 21-300-13 $\left(S_{1} S_{3}\right), 21-379-64\left(S_{3} S_{19}\right), 21-502-1\left(S_{1} S_{24}\right)$, 21-555-13 $\left(S_{3} S_{19}\right)$, Co-op $14\left(S_{3} S_{5}\right)$, Co-op $16\left(S_{3} S_{5}\right)$, D1R102T116 $\left(S_{3} S_{24}\right)$, D1R103T245 $\left(S_{3} S_{24}\right)$, and Scifresh $\left(S_{2} S_{24}\right)$ (Table 4).

There are 11 cultivars from the Epagri Apple Breeding Program that had already been genotyped (Albuquerque Junior et al. 2011): 'Baronesa' $\left(S_{3} S_{9}\right)$, 'Duquesa' $\left(S_{2} S_{3}\right)$, 'Fred Hough' $\left(S_{5} S_{19}\right)$, 'Catarina' $\left(S_{1} S_{19}\right)$, 'Fuji Suprema' $\left(S_{1} S_{9}\right)$, 'Condessa' $\left(S_{2} S_{?}\right)$, 'Imperatriz' $\left(S_{3} S_{5}\right)$, 'Daiane' $\left(S_{3} S_{5}\right)$, 'Joaquina' $\left(S_{5} S_{19}\right)$, 'Lisgala' $\left(S_{2} S_{5}\right)$, 'Primícia' $\left(S_{24} S_{?}\right)$, and 'Princesa' $\left(S_{3} S_{5}\right)$. Other international apple cultivars are likewise important for the Epagri Apple Breeding Program and have been used in several planned crosses. The following cultivars have been genotyped for their $S$-alleles: 'Akane' $\left(S_{7} S_{24}\right)$ (Kitahara et al. 2000), 'Cripps Pink' $\left(S_{2} S_{23}\right)$ (Broothaerts et al. 2004), 'Florina' $\left(S_{2} S_{3}\right)$ (Long et al. 2010), 'Liberty' $\left(S_{3} S_{5} S_{10}\right)$ (Broothaerts et al. 2004), Malus floribunda $\left(S_{26} S_{7}\right)$ (Broothaerts 2003), 'Priscila' $\left(S_{9} S_{20}\right)$ (Morita et al. 2009), 'Red Free' $\left(S_{3} S_{7}\right)$ (Morita et al. 2009), and 'Sansa' $\left(S_{5} S_{7}\right)$ (Kitahara and Matsumoto 2002).

The compatibility levels between the genotypes based on identification of the $S$-alleles are presented in Table 5 . Crosses using the genotypes within groups (Table 5) are impossible because they are incompatible. In the crosses between groups, there is at least semi-compatibility between the groups and the other genotypes, except for triploid genotypes. Pollen from triploid plants is sterile because the chromosomes are unequally divided during meiosis (Sedov et al. 2017). For that reason, triploid plants can only be used as a female parent.

Eleven different $S$-alleles were identified in the 42 genotypes evaluated (Figure 1). The $S_{3}$ and $S_{5}$ alleles were most frequently identified ( $30.2 \%$ and $18.6 \%$, respectively). One of the reasons for the higher frequency of these alleles is that 26 of the 42 genotypes tested were direct or indirect descendants from the cultivars 'Imperatriz' $\left(S_{3} S_{5}\right.$ ) (Albuquerque

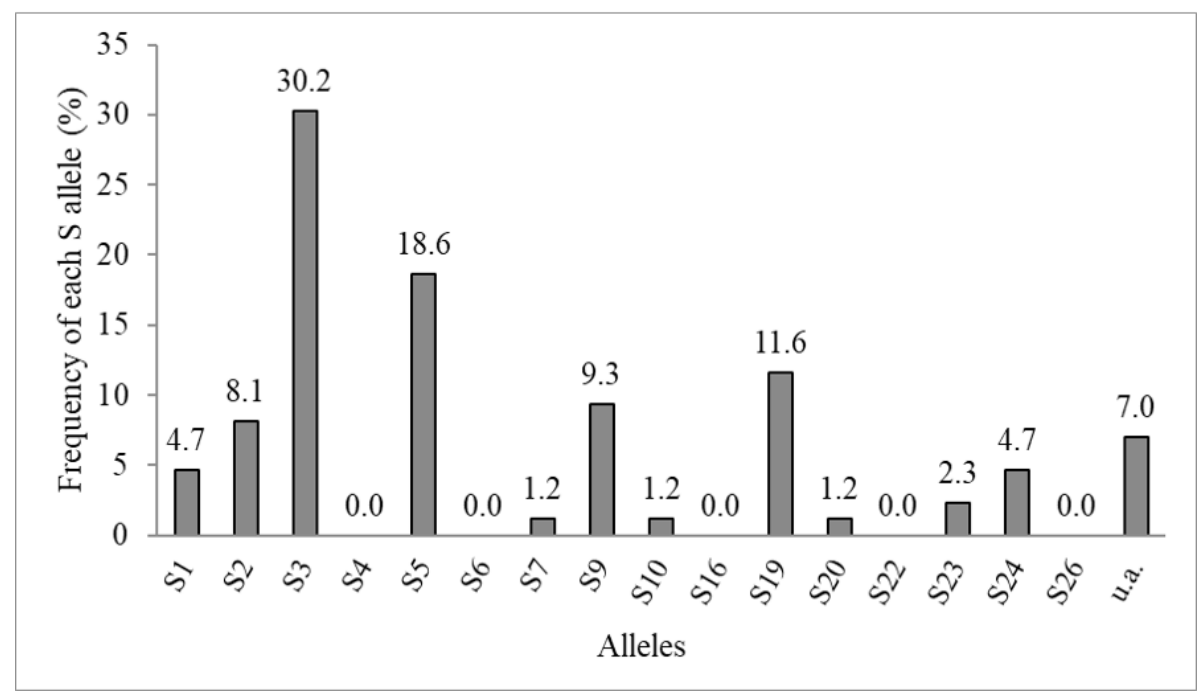

Figure 1. Frequency of occurrence of each S-allele in 42 apple genotypes: six cultivars developed by Epagri; 20 selections of the Elite Germplasm Collection of the Epagri Apple Breeding Program; and 16 accessions from the Apple Germplasm Bank of Epagri, located in Caçador, SC. u.a.: unidentified alleles. 


\section{TL Brancher et al.}

Junior et al. 2011), 'Golden Delicious' $\left(S_{2} S_{3}\right)$ (Matsumoto et al. 1999), and/or 'Gala' $\left(S_{2} S_{5}\right)$ (Matsumoto et al. 1999). For a long time, these three genotypes served as the basis for the crosses of the Epagri Apple Breeding Program. A consequence of selection through breeding is that the bottleneck in genetic variability is indirectly reflected in the higher frequency of a few $S$-alleles, such as $S_{3}$ and $S_{5}$ in this situation. Larsen et al. (2016) showed a higher frequency of $S_{3}$ alleles (28\%) among 432 genotypes of the genus Malus. In European apple cultivars, Dreesen et al. (2010) identified $S_{2}, S_{3^{\prime}} S_{5^{\prime}}$, and $S_{9}$ as the most common $S$-alleles. Meanwhile, Hegedús (2006) reported that the $S_{2}, S_{3}, S_{5}, S_{7}, S_{9}$, and $S_{10}$ alleles were the most frequent among the commercial apple cultivars, due to the extensive use of the genotypes 'Golden Delicious', 'Delicious', 'Jonathan', 'McIntosh', and 'Cox's Orange Pippin' in apple breeding programs around the world.

According to Halász et al. (2011) and De Franceschi et al. (2016), the presence of the $S_{2}, S_{3}$, and $S_{5}$ alleles is associated with resistance to apple scab (Venturia inaequalis). Apparently, none of these $S$-alleles are linked to the gene of vertical resistance against apple scab (Rvi6), but somehow they are linked to different resistance levels, close to genes of minor effect on horizontal resistance (Halász et al. 2011). Indirect selection for these alleles can be performed by breeders, and most of the parents used for generating scab-resistant plants have at least one of these alleles $\left(S_{2}, S_{3}\right.$, and $\left.S_{5}\right)$, explaining their higher frequency in elite genotypes of the Epagri Breeding Program.

The identification of the $S$-alleles in the genotypes evaluated allows breeders to plan crosses. Furthermore, it provides important information for other breeding programs, which can use the genotypes evaluated in this study as a genetic source in their research.

\section{ACKNOWLEDGMENTS}

The authors gratefully acknowledge the assistance of Dr. David Chagné (The New Zealand Institute for Plant and Food Research, Ltd.) for the English grammar review. The authors wish to thank the Empresa de Pesquisa Agropecuária e Extensão Rural de Santa Catarina (EPAGRI), the National Council for Scientific and Technological Development (Conselho Nacional de Desenvolvimento Científico e Tecnológico - CNPq/Grant number 404475/2016-7), the Coordination for the Improvement of Higher Education Personnel (Coordenação de Aperfeiçoamento de Pessoal de Nível Superior - CAPES), the Santa Catarina Research Foundation (Fundação de Amparo à Pesquisa e Inovação do Estado de Santa Catarina FAPESC), Santa Catarina State University (Universidade do Estado de Santa Catarina - UDESC), and the Financier of Studies and Projects (Financiadora de Estudos e Projetos - FINEP) for financial support for this research and for the scholarships granted.

\section{REFERENCES}

Agapito-Tenfen SZ, Dantas ACM, Denardi F and Nodari RO (2015) Identification of the Er1 resistence gene and RNase S-alleles in Malus prunifolia var. ringo rootstock. Scientia Agricola 72: 62-68.

Akbari M, Yamaguchi M, Maejima T, Otagaki S, Shiratake K and Matsumoto S (2016) Apple cultivation and breeding in Afghanistan: S-RNase genotypes and search system for suitable cultivar combination. International Journal of Agronomy 2016: 1-5.

Albuquerque Junior CL de, Denardi F, de Dantas ACM and Nodari RO (2011) The self-incompatible RNase S-alleles of Brazilian apple cultivars. Euphytica 181: 277-284.

Benson DA, Cavanaugh M, Clark K, Karsch-Mizrachi I, Lipman DJ, Ostell J and Sayers EW (2013) GenBank. Nucleic Acids Research 41: D36-D42.

Bošković R and Tobutt KR (1999) Correlation of stylar ribonuclease isoenzymes with incompatibility alleles in apple. Euphytica 107: 29-43.

Breen KC, Tustin DS, Palmer JW, Hedderley DI and Close DC (2016) Effects of environment and floral intensity on fruit set behaviour and annual flowering in apple. Scientia Horticulturae 210: 258-267.

Broothaerts W (2003) New findings in apple S-genotype analysis resolve previous confusion and request the re-numbering of some S-alleles. Theoretical and Applied Genetics 106: 703-714.

Broothaerts W, Van Nerum I and Keulemans J (2004) Update on and review of the incompatibility (S-) genotypes of apple cultivars. HortScience 39: 943-947.

De Franceschi P, Cova V, Tartarini S and Dondini L (2016) Characterization of a new apple S-RNase allele and its linkage with the Rvi5 gene for scab resistance. Molecular Breeding 36: 1-11.

Denardi F, Kvitschal MV and Hawerroth MC (2019a) A brief history of the forty-five years of the Epagri apple breeding program in Brazil. Crop Breeding and Applied Biotechnology 19: 347-355.

Denardi F, Kvitschal MV, Hawerroth MC and Argenta LC (2019b) 'SCS425 Luiza': new apple cultivar with medium chilling requirement and resistant to glomerella leaf spot (Colletotrichum spp.). Revista Brasileira de Fruticultura 41: e-109.

Denardi F, Kvitschal MV, Hawerroth MC and Argenta LC (2019c) SCS426 
Self-incompatibility alleles in important genotypes for apple breeding in Brazil

Venice: new apple cultivarwith glomerella leaf spot resistance and picking time in March. Crop Breeding and Applied Biotechnology 19: 481-486.

Dreesen RSG, Vanholme BTM, Luyten K, Van Wynsberghe L, Fazio G, Roldán-Ruiz I and Keulemans J (2010) Analysis of Malus S-RNase gene diversity based on a comparative study of old and modern apple cultivars and European wild apple. Molecular Breeding 26: 693-709.

Halász J, Hegedűs A, György Z, Pállinger É and Tóth M (2011) S-genotyping of old apple cultivars from the Carpathian basin: methodological, breeding and evolutionary aspects. Tree Genetics \& Genomes 7: 1135-1145.

Hawerroth MC, Brancher TL and Kvitschal MV (2018) Dissimilaridade entre genótipos elite de macieira da Epagri com base na caracterização fenotípica e molecular. Agropecuária Catarinense 31: 67-72.

Hegedüs A (2006) Review of the self-incompatibility in apple (Malus $\times$ domestica Borkh., syn.: Malus pumila Mill.). International Journal of Horticultural Science 12: 31-36.

Janssens GA, Goderis IJ, Broekaert WF and Broothaerts W (1995) A molecular method for S-allele identification in apple based on allelespecific PCR. Theoretical and Applied Genetics 91: 691-698.

Kasajima I, Kikuchi T and Yoshikawa N (2017) Rapid identification of apple (Malusx domestica Borkh.) S alleles using sequencing-based DNA marker APPLid. Plant Biotechnology (Tokyo) 34: 97-106.

Kim HT, Moriya S, Okada K, Abe K, Park JI, Yamamoto T and Nou IS (2016) Identification and characterization of S-RNase genes in apple rootstock and the diversity of $S$-RNases in Malus species. Journal of Plant Biotechnology 43: 49-57.

Kitahara K and Matsumoto S (2002) Sequence of the S10 cDNA from 'McIntosh' apple and a PCR-digestion identification method. HortScience 37: 187-190.

Kitahara K, Soejima J, Komatsu H, Fukui H and Matsumoto S (2000) Complete sequences of the S-genes, $\mathrm{Sd}$ - and Sh-RNase cDNA in apple. HortScience 35: 712-715.

Larsen B, Ørgaard M, Toldam-Andersen TB and Pedersen C (2016) A high-throughput method for genotyping S-RNase alleles in apple. Molecular Breeding 36: 24.

Lefort F and Douglas GC (1999) An efficient micro-method of DNA isolation from mature leaves of four hardwood tree species Acer, Fraxinus, Prunus and Quercus. Annals of Forest Science 56: 259-263.
Long S, Li M, Han Z, Wang K and Li T (2010) Characterization of three new S-alleles and development of an S-allele-specific PCR system for rapidly identifying the S-genotype in apple cultivars. Tree Genetics and Genomes 6: 161-168.

Maliepaard C, Alston FH, Van Arkel G, Brown LM, Chevreau E, Dunemann F, Evans KM, Gardiner S, Guilford P, Van Heusden AW, Janse J, Laurens F, Lynn JR, Manganaris AG, den Nijs APM, Periam N, Rikkerink E, Roche $P$, Ryder C, Sansavini S, Schmidt H, Tartarini S, Verhaegh JJ, VVrielink-van Ginkel M and King GJ (1998) Aligning male and female linkage maps of apple (Malus pumila Mill.) using multi-allelic markers. Theoretical and Applied Genetics 97: 60-73.

Matsumoto S, Komori S, Kitahara K, Imazu S and Junichi Soejima (1999) S-genotypes of 15 apple cultivars and self-compatibility of "Megumi". Journal of the Japanese Society for Horticultural Science 68: 236241.

Morita J, Abe K and Matsumoto S (2009) S-RNase genotypes of apple cultivars grown in Japan and development of a PCR-RFLP method to identify the S 6-and S 21-RNase alleles. Journal of Horticultural Science and Biotechnology 84: 29-34.

Muñoz-Sanz JV, Zuriaga E, Cruz-García F, McClure B and Romero C (2020) Self-(In)compatibility systems: Target traits for crop-production, plant breeding, and biotechnology. Frontiers in Plant Science 11: 195.

Pereira-Lorenzo S, Fischer M, Ramos-Cabrer AM and Castro I (2018) Apple (Malus spp.) Breeding: Present and future. Springer, Cham, p. 3-29.

Revers LF, Lampe VS, de Oliveira PRD, Camargo UA and de Lima JC (2005) Uso prático de marcadores moleculares para seleção assistida no melhoramento de uvas de mesa apirênicas. Revista Brasileira de Fruticultura 28: 104-108.

Sakurai K, Brown SK and Weeden N (2000) Self-incompatibility alleles of apple cultivars and advanced selections. Hortscience 35: 116-119.

Sassa H, Kakui H, Miyamoto M, Suzuki Y, Hanada T, Ushijima K, Kusaba M, Hirano H and Koba T (2007) S locus F-box Brothers: multiple and pollen-specific F-box genes with S haplotype-specific polymorphisms in apple and Japanese pear. Genetics 175: 1869-1881.

Sedov EN (2014) Apple breeding programs and methods, their development and improvement. Russian Journal of Genetics: Applied Research 4: 43-51.

Sedov EN, Sedysheva GA, Makarkina MA and Serova ZM (2017) Development of triploid apple cultivars as a priority in selection. Russian Journal of Genetics: Applied Research 7: 773-780.

(cc) EY This is an Open Access article distributed under the terms of the Creative Commons Attribution License, which permits unrestricted use, distribution, and reproduction in any medium, provided the original work is properly cited. 